\title{
A 22 570-year record of vegetational and climatic change from Wenhai Lake in the Hengduan Mountains biodiversity hotspot, Yunnan, Southwest China
}

\author{
Y. F. Yao ${ }^{1,3}$, X. Y. Song ${ }^{2}$, A. H. Wortley ${ }^{3}$, S. Blackmore ${ }^{3}$, and C. S. Li $^{1}$ \\ ${ }^{1}$ State Key Laboratory of Systematic and Evolutionary Botany, Institute of Botany, Chinese Academy of Sciences, Xiangshan, \\ 100093 Beijing, China \\ ${ }^{2}$ Shanxi Agricultural University, Taigu 030801, Shanxi, China \\ ${ }^{3}$ Royal Botanic Garden Edinburgh, 20a Inverleith Row, Edinburgh EH3 5LR, Scotland, UK \\ Correspondence to: Y. F. Yao (yaoyf@ibcas.ac.cn) and C. S. Li (lics@ibcas.ac.cn)
}

Received: 14 July 2014 - Published in Biogeosciences Discuss.: 18 September 2014

Revised: 16 February 2015 - Accepted: 22 February 2015 - Published: 11 March 2015

\begin{abstract}
The Hengduan Mountains, with their strong altitudinal vegetation zonation, form a biodiversity hotspot which offers the potential for comparison between sites in order to understand how this zonation arose and how it has responded to climate change and human impacts through time. This paper presents a 22570 -year pollen record of vegetational and climatic change based on a core $320 \mathrm{~cm}$ in depth collected from Wenhai Lake on Jade Dragon Snow Mountain, one of the highest peaks in the Hengduan Mountains region of Yunnan, Southwest China. From 22570 to $21140 \mathrm{cal}$ yr BP, the vegetation was dominated by broad-leaved forest (comprising mainly Quercus, Betula and Castanopsis), accompanied by needle-leaved forest (mainly Pinus and Abies), indicating a rather cold and dry climate relative to the present followed by cold and wet conditions. In the period between 21140 and $19350 \mathrm{cal} \mathrm{yr} \mathrm{BP}$, the vegetation was still dominated by broad-leaved forest and needle-leaved forest as before but with a notable increase in Betula pollen and a sharp decrease in Quercus pollen, implying a relatively cold and dry climate with several fluctuations in humidity. The period 19350 to 17930 cal yr BP was a transition stage from broad-leaved forest to needle-leaved forest, with a dramatic decrease in Quercus pollen and a maximum reading for Abies pollen, reflecting the coldest and driest climate since $22570 \mathrm{cal} \mathrm{yr} \mathrm{BP}$. The expansion in needle-leaved forest dominated by Pinus and Abies (22 570-17930 cal yr BP) along with an increase of Betula might correspond to the Last Glacial Maximum (LGM; the start of the LGM perhaps occurred prior to the basal age of the core). Between 17930 and 9250 cal yr BP,
\end{abstract}

needle-leaved forest declined and broad-leaved forest began to increase at first, suggesting increases in temperature and humidity, while towards the end of the period, needle-leaved forest expanded and broad-leaved forest shrank, indicating a colder and drier climate, possibly corresponding to the Younger Dryas. From 9250 cal yr BP to the present, the vegetation has been dominated by needle-leaved forest (comprising mainly Pinus, Abies and Tsuga), interspersed with broadleaved Quercus and Betula, reflecting a significant decline in humidity from the early to late Holocene. During this period, human activity likely increased in this region, with impacts on the vegetation such as a distinct decrease in Pinus and Quercus pollen and an increase in Polygonaceae pollen in the upper $30 \mathrm{~cm}$ of the core. The marked decline in Quercus pollen compared with the early stage of this period, in particular, in the Wenhai core can be correlated with that observed in the Haligu core (situated about $2 \mathrm{~km}$ away) between 2400 cal yr BP and the present.

\section{Introduction}

The Hengduan Mountains are located in the north of the Mountains of Southwest China biodiversity hotspot, the most biologically diverse temperate ecosystem in the world (Conservation International, 2010), sandwiched between the Honghe Basin to the east and the Qinghai-Xizang Plateau to the west. They comprise five main ridge systems char- 
acterized by vertical vegetation zonation and separated by four deep drainage systems, created during the Himalayan orogeny beginning in the Tertiary and continuing into the Quaternary (Myers et al., 2000; Ying, 2001). The floristic diversity of the region is particularly high: the Hengduan Mountains are situated in Yunnan Province, which, despite covering just $4 \%$ of China's land area, contains ca. 15000 species of higher plants, almost $50 \%$ of the country's total.

The marked altitudinal zonation of vegetation in the Hengduan Mountains offers the potential to compare between sites in order to build up an understanding of how this zonation arose and how it responds, through time, to climate change and human impacts. Jade Dragon Snow Mountain (rising to $5596 \mathrm{~m}$ a.s.l.) is one of the highest peaks in the Hengduan Mountains region, and is particularly appropriate for the study of past and present diversity using palynological data because it supports a number of natural wetlands and lakes containing abundant, well-preserved palynomorphs, at a range of altitudes. Thus, sampling of core sediments from different sites has the potential to generate pollen data relative to both time and altitude (at a given locality), which will ultimately enable us to estimate changes in both floristic composition and diversity over time and their response to climatic change.

During the past decade, pollen analysis has been employed extensively for understanding Quaternary vegetation and climate history in China (e.g. Xu et al., 2002; Xiao et al., 2004; Zhao et al., 2007; Li et al., 2011; An et al., 2013; Cao et al., 2013; Jiang et al., 2013). However, few such studies have been conducted in the Hengduan Mountains (Jiang et al., 1998; Shen et al., 2006; Jones et al., 2012; Song et al., 2012; Cook et al., 2013; Xiao et al., 2014). Previously, we have investigated changing climate and vegetation over the past 9300 years based on pollen analyses of a core $400 \mathrm{~cm}$ in depth from a wetland site at Haligu (3277 m) on Jade Dragon Snow Mountain (Song et al., 2012). This paper presents a 22570 -year record of vegetational and climatic change from Wenhai Lake, also on Jade Dragon Snow Mountain. We aim to use pollen data to develop insights into changing floristic diversity and to draw inferences about past climate and anthropogenic influences in the region during the late Quaternary.

\section{Study area}

Wenhai Lake $\left(26^{\circ} 58^{\prime} 59^{\prime \prime} \mathrm{N}, 100^{\circ} 09^{\prime} 54^{\prime \prime} \mathrm{E}\right)$, an enclosed icescour lake at an altitude of $3080 \mathrm{~m}$, is located at the southern end of Jade Dragon Snow Mountain in Yulong County of Lijiang City, northwestern Yunnan, Southwest China (Fig. 1). It forms part of Lashihai Swamp Natural Reserve and is approximately $23 \mathrm{~km}$ northwest of Lijiang. The lake has a surface area of about $0.16 \mathrm{~km}^{2}$, with a maximum water depth of ca. $4 \mathrm{~m}$. It is hydrologically recharged by rainfall and glacial meltwater from the surrounded mountains, without river wa- ter inputting into the lake. It is a seasonal lake, receiving abundant rainfall in the rainy season (May to October) and less rainfall in the dry season (November to April). The outflow is dammed, with a dam constructed in 2012. Therefore, the source of lake sediment is relatively simple and stable. This area is a key region linking the Qinghai-Xizang Plateau with the Yungui Plateau, and also is a boundary region between the Hengduan Mountains area of northwestern Yunnan and the plateau area of eastern Yunnan. More than a thousand years ago, Wenhai was an important stop on the ancient "Tea-Horse Road", a route for trading tea and horses between inland agricultural and remote nomadic regions (Luo, 2003). Yulong County is home to several ethnic minorities, with the Naxi being most numerous.

The study area is strongly influenced by the southwest monsoon coming from the Indian Ocean. Thus the summers are warm and humid and the winters cool and dry. The mean annual temperature (MAT) and mean annual precipitation (MAP) measured at Lijiang (situated below the study site at about $2200 \mathrm{~m}$ ) are $12.8^{\circ} \mathrm{C}$ and $935 \mathrm{~mm}$, respectively. About $90 \%$ of the annual precipitation falls in summer, between June and October. The warmest month is July, with a mean temperature of $17.9^{\circ} \mathrm{C}$, and the coldest month is January, with a mean temperature of $5.9^{\circ} \mathrm{C}$ (Feng et al., 2006).

The regional vegetation and climate of the Jade Dragon Snow Mountain area are strongly related to elevation gradients. At increasing elevations on the mountain slopes, MAT shows a decreasing trend, while MAP displays a reverse trend. For example, MAT and MAP are $12.6^{\circ} \mathrm{C}$ and $772 \mathrm{~mm}$, respectively, at $2393 \mathrm{~m}$; MAT decreases to $5.4^{\circ} \mathrm{C}$ and MAP increases to $1600 \mathrm{~mm}$ at $3200 \mathrm{~m}$; and MAT further decreases to -3.3 to $-4.7^{\circ} \mathrm{C}$ and MAP increases to more than $2400 \mathrm{~mm}$ at the snow line $(4800 \mathrm{~m}$; He et al., 2000a, b). Four main vegetation zones can be recognized: zone 1, semi-humid evergreen broad-leaved forest-pine forest (about 2400-3000 m); zone 2, needle- and broad-leaved mixed forest-sclerophyllous evergreen broad-leaved forest (about 3000-3300 m); zone 3, cold-temperate needle-leaved forest (about 3300-4200 m); and zone 4, alpine heath scrub and meadow (above $4200 \mathrm{~m}$; Wu et al., 2006). From our personal observations, the present vegetation around the Wenhai Lake catchment is dominated by oaks (Quercus pannosa Hand.-Mazz) and pines, primarily Pinus yunnanensis, with $P$. armandii Franch. at slightly lower elevations, and smaller numbers of Tsuga dumosa (D. Don) Eichler and P. densata Mast. are also present. Here, the most abundant shrubs are ericaceous, including rhododendron species, especially Rhododendron mucronatum (Blume) G. Don, R. racemosum Franch., $R$. yunnanense Franch. and $R$. delaveyi Franch., together with Vaccinium bracteatum Thunb. and Pieris formosa (Wallich) D. Don. Herbaceous taxa are diverse, with some of the most speciose genera being Anemone, Gentiana, Primula and Roscoea. This area is now heavily influenced by human activities, such as felling of timber and grazing, so some patches are barren of vegetation. 


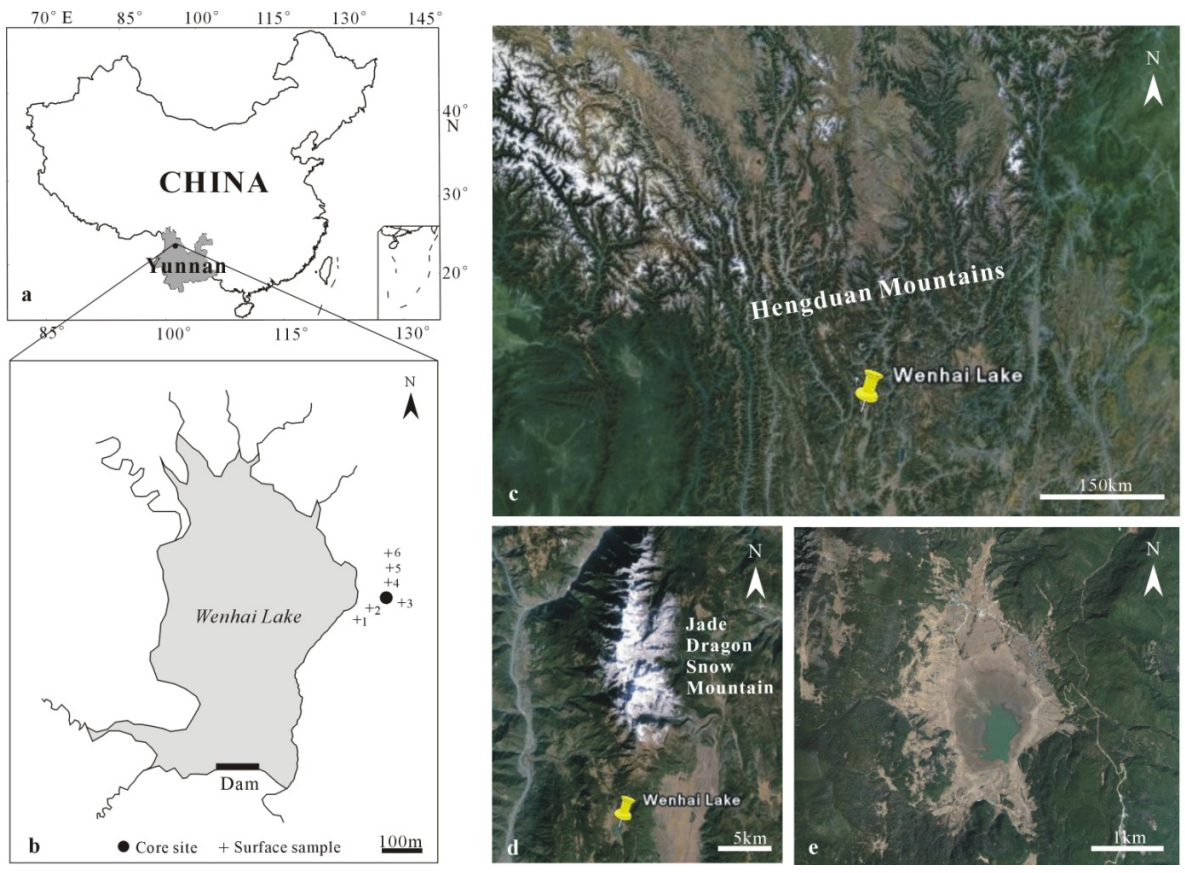

Figure 1. (a) The location of Wenhai Lake in northwestern Yunnan, China, (b) the position of core and surface soil samples, (c) the location of Wenhai Lake in the Hengduan Mountains, (d) the location of Wenhai Lake on Jade Dragon Snow Mountain, and (e) an enlarged photograph of Wenhai Lake (c, $\mathbf{d}$ and $\mathbf{e}$ are taken from Google Earth).

\section{Materials and methods}

\subsection{Coring and sampling}

A sediment core $320 \mathrm{~cm}$ in depth was obtained from Wenhai Lake in January 2005 using a Russian corer, which consists of a $40 \mathrm{~cm}$ long steel chamber (diameter $10 \mathrm{~cm}$ ) and $1 \mathrm{~m}$ long steel rods. Coring was done in $40 \mathrm{~cm}$ overlapping steps $(0-40,40-80,80-120 \mathrm{~cm}$, etc.). To avoid contamination, the chamber was cleaned carefully before starting each new round of coring. The core was labelled in the field, wrapped in plastic foil and placed in halved PVC tubes. A detailed lithological description of the core is presented in Fig. 2.

\subsection{Radiocarbon dating}

Two samples from the core, at 155 and $320 \mathrm{~cm}$ in depth, were taken for accelerator mass spectrometry (AMS) radiocarbon dating, which was performed at the Scottish Universities Environmental Research Centre (SUERC) in Glasgow, Scotland, UK. The ${ }^{14} \mathrm{C}$ ages are quoted in conventional years before present (before AD 1950). Bulk samples from the core were used because fragments of plant material suitable for analysis were not present. Age calibration was set up using the calibration curve from Reimer et al. (2004) by means of the calibration program OxCal v3.10 (Bronk, 2005). Date ranges are cited in calibrated years $\mathrm{AD} / \mathrm{BC}$ at $95 \%$ probabil- ity, with end points rounded to the nearest 10 years (Mook, 1986; Foster et al., 2008).

\subsection{Pollen analysis}

Six surface soil samples near the core were collected for comparison with the preserved pollen assemblage. Thirtytwo samples were taken from the core itself, at $10 \mathrm{~cm}$ intervals, for pollen analysis. Thirty grams of each sample was processed by means of heavy liquid separation (Moore et al., 1991; Li and Du, 1999) followed by acetolysis (Erdtman, 1960). Pollen grains and spores were identified using modern pollen slides, palynological literature and monographs (IBCAS, 1976; IBSCIBCAS, 1982; Wang et al., 1995). All samples yielded abundant, well-preserved palynomorphs. Pollen samples were examined using a Leica DM 2500 light microscope at a magnification of $400 \times$, and at least 300 pollen grains and spores were counted in each sample. Pollen grains and spores were divided into four categories: trees and shrubs, herbs, pteridophytes, and aquatic taxa. Pollen data were expressed as percentages and graphed using Tilia.Graph, and pollen zones were determined with CONISS in the Tilia program (Grimm, 1997). 


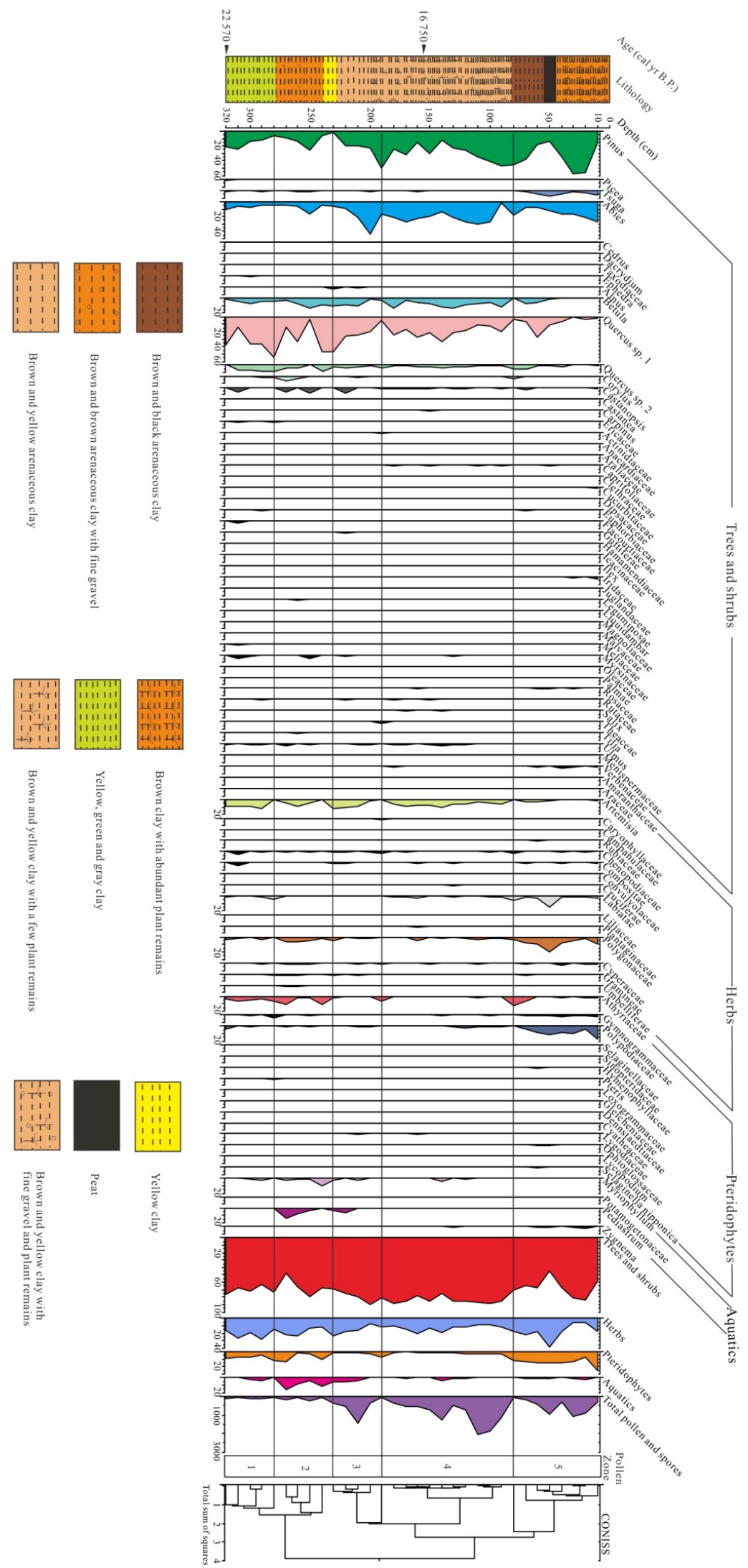

Figure 2. Pollen percentage diagram from Wenhai Lake, northwestern Yunnan, China. 


\section{Results}

\subsection{Chronology}

Two AMS radiocarbon dates, $14075 \pm 40 \mathrm{yr}$ BP $(17150$ $16350 \mathrm{cal} \mathrm{yr} \mathrm{BP})$ at a depth of $155 \mathrm{~cm}$ and $19075 \pm 50 \mathrm{yr}$ BP (22 760-22 380 cal yr BP) at a depth of $320 \mathrm{~cm}$, give a relatively reliable basis for deciphering the vegetation and climate history in and surrounding Wenhai Lake. The lithology of the entire core is mainly characterized by clay with the exception of a peat deposit at depth of $45-55 \mathrm{~cm}$. Given continuity and stability of sedimentation during the past 22570 years, an age-depth curve in cal yr BP, reflecting the sedimentation pattern, can be constructed for the core (see the Supplement). Although the age-depth model is obtained based on two dates, it roughly shows the sedimentation rates are ca. 0.1 and $0.28 \mathrm{~mm} \mathrm{yr}^{-1}$ for the depths of $0-155$ and $155-320 \mathrm{~cm}$, respectively. Ages of other depths are deduced by assuming that the sedimentation rate is constant for the lower and upper sections of the core, i.e. $9250 \mathrm{cal} \mathrm{yr} \mathrm{BP}$ at $80 \mathrm{~cm}, 17930 \mathrm{cal} \mathrm{yrBP}$ at $190 \mathrm{~cm}, 19350 \mathrm{cal} \mathrm{yr} \mathrm{BP}$ at $230 \mathrm{~cm}$, and $21140 \mathrm{cal} \mathrm{yr} \mathrm{BP}$ at $280 \mathrm{~cm}$ depth, which are determined as the timing of the changes of the pollen zones.

\subsection{Pollen analysis}

\subsubsection{Surface samples}

Fifty palynomorphs were identified from the six surface soil samples collected in close proximity to the core, including 29 families and 7 genera of angiosperms, 3 genera of gymnosperms, 9 families and 1 genus of pteridophytes, and 1 genus of alga (see the Supplement). The pollen assemblage is dominated by trees and shrubs, at percentages ranging from 79.5 to $97.0 \%$ of the total pollen and spores. $\mathrm{Pi}$ nus pollen $(62.3-87.1 \%)$ dominates in all six surface samples, followed by Abies (3.3-10.7\%), Quercus (0-5.5\%) and Ericaceae $(0-4.1 \%)$. Herb pollen is present at low percentages (1.8-4.1\%), and comprises Artemisia, other Compositae, Caryophyllaceae, Chenopodiaceae, Convolvulaceae, Cruciferae, Cyperaceae, Gramineae, Labiatae, Liliaceae and Polygonaceae. Pteridophyte spores account for $0.3-15.3 \%$, including Athyriaceae, Cyatheaceae, Gymnogrammaceae, Hymenophyllaceae, Loxogrammaceae, Lygodiaceae, Plagiogyriaceae, Polypodiaceae, Pteris and Sinopteridaceae. Aquatic plants are recorded at low percentages (0-3\%), comprising Myriophyllum and Zygnema. This pollen assemblage is consistent with the local vegetation of the lake basin and the surrounding mountains, reflecting a needle-leaved forest dominated by Pinus and accompanied by some broad-leaved components, e.g. Quercus and Ericaceae.

\subsubsection{Pollen diagram zonation and description}

Pollen analysis of the core samples shows a high degree of taxonomic diversity. The palynoflora comprises 83 paly- nomorphs, which can be identified to 45 families and 13 genera of angiosperms, 1 family and 7 genera of gymnosperms, 12 families and 3 genera of pteridophytes, and 2 genera of algae (see the Supplement). Some of the selected palynomorphs extracted from the core are illustrated in the Supplement.

A greater diversity of palynomorphs was recovered from the core samples than from the surface samples. However, many of the taxa found in the core but missing from surface samples are not present in the upper part of the core and are no longer present in the immediate area and thus do not contribute to the local pollen rain. Examples include Cedrus, Dacrydium and Taxodium amongst the gymnosperms and the angiosperm taxa Actinidiaceae, Anacardiaceae, Carpinus, Clethraceae, Flacourtiaceae, Icacinaceae, Juglandaceae, Liquidambar, Myrsinaceae, Palmae and Tilia. Some of these taxa have a subtropical distribution, and their closest occurrence to the study site is at much lower elevation near the Jinsha River or considerably further south in Yunnan. Other taxa such as Araceae, Araliaceae, Campanulaceae, Caprifoliaceae, Caryophyllaceae and Umbelliferae are present in the immediate area but are entomophilous plants with relatively lower pollen production which might be expected to be under-represented in the local pollen rain.

A cluster analysis performed using Tilia (with CONISS) divided the pollen diagram into five distinct zones (Fig. 2). Brief descriptions of each zone are as follows.

Pollen zone 1 (320-280 cm: 22 570-21 140 cal yr BP): this zone is characterized by a dominance of tree and shrub pollen $(72.9-81.3 \%)$, followed by herbs $(6.3-20 \%)$, ferns $(4.2-$ $12.5 \%)$ and aquatics $(0-4.2 \%)$. Among the trees and shrubs, the percentage of broad-leaved elements $(42.2-70.8 \%)$ is higher than that of conifers $(10.4-33.9 \%)$. The trees and shrubs are dominated by the broad-leaved taxa Quercus (20$62.5 \%$, including Quercus sp. 1 and sp. 2), Betula (1.8$7.6 \%)$, Castanopsis (0-6.7\%) and the coniferous taxa Pinus (6.3-24.4\%) and Abies (4.2-10.1\%). Pollen grains of other coniferous plants such as Picea and Tsuga, and broad-leaved plants such as Corylus, Ulmus and Ericaceae are also present in minute quantities. Herbs are represented by Artemisia ( 0 $11.5 \%)$, coupled with Chenopodiaceae ( $0-4.4 \%)$, Compositae $(0-4.4 \%)$, Labiatae $(0-4.2 \%)$, and Polygonaceae $(0$ $3.7 \%)$. Fern taxa include Athyriaceae (3.7-6.7\%), Polypodiaceae $(0-4.6 \%)$, Gymnogrammaceae $(0-4.2 \%)$ and Pteris (0-2.1\%). Two taxa of aquatic plants, Myriophyllum and $\mathrm{Pe}$ diastrum, are recorded, at $0-3.1 \%$ and $0-1.0 \%$, respectively.

The pollen assemblages of pollen zone 1 and the surface samples are both dominated by tree and shrub pollen, represented by 72.9-81.3 and 79.5-97\%, respectively. Quercus pollen (20-62.5\%) dominates the trees and shrubs of pollen zone 1, followed by Pinus, Abies, Betula and Castanopsis. In contrast, Pinus pollen (62.3-87.1\%) dominates the trees and shrubs of the surface samples, followed by Abies, Quercus and Ericaceae. The percentage of herb pollen is comparatively high in pollen zone $1(6.3-20 \%)$ compared to the 
surface samples (1.8-4.1\%). Similar percentages of pteridophyte spores (pollen zone 1: 4.2-12.5\%; surface samples: $0.3-15.3 \%$ ) and aquatics (pollen zone 1: $0-4.2 \%$; surface samples: $0-3 \%$ ) are recorded in pollen zone 1 and the surface samples.

Pollen zone 2 (280-230 cm: 21 140-19350 cal yr BP): in this zone, two distinct characteristics are observed: firstly a sharp increase in the aquatic pollen percentage, reaching a maximum (16.7\%) for the entire profile at a depth of $270 \mathrm{~cm}$, which is attributed to the prevalence of Myriophyllum and Pediastrum. Secondly, trees and shrubs continue to dominate in this zone. The percentage of trees and shrubs ranges from 52.3 to $79.6 \%$. As in pollen zone 1 , broad-leaved trees (34.4-65.2\%) still occupy a higher percentage than conifers $(8.6-45.2 \%)$. Among the conifers, it should be noted that Pinus pollen reaches its lowest value $(2.1 \%)$ for the whole profile at a depth of $230 \mathrm{~cm}$. Broadleaved trees, i.e. Quercus (4.1-56.5\%), Betula (3.4-13.7\%), Castanopsis (0-8.5\%) and Corylus (0-6.3\%), together with herbaceous taxa, i.e. Artemisia $(0-12.8 \%)$ and Polygonaceae (2.2-6.9\%), continue to play an important role in this zone. In addition, some new broad-leaved elements, Alnus, Carpinus, Actinidiaceae, Ilex, Leguminosae, Tilia, Cruciferae and Plantaginaceae, are found sporadically for the first time. The percentage of fern spores $(1.3-13.8 \%)$ remains at almost the same level as in pollen zone 1. Athyriaceae spores show a slight increase (up to $10.9 \%$ ), but Gymnogrammaceae (0$0.4 \%)$, Polypodiaceae $(0-1.1 \%)$ and Pteris $(0-1.1 \%)$ display minor decreases.

Tree and shrub pollen dominates the pollen assemblages of both pollen zone 2 and the surface samples, but its percentage in pollen zone $2(52.3-79.6 \%)$ is lower than in the surface samples (79.5-97\%). Quercus pollen dominates the trees and shrubs of pollen zone $2(4.1-56.5 \%)$, compared to the dominance of Pinus pollen (62.3-87.1\%) in the surface samples. The percentages of herb pollen (pollen zone 2: 2.2-21.2\%; surface samples: $1.8-4.1 \%$ ) and aquatics (pollen zone 2: $4.1-16.7 \%$; surface samples: 0-3\%) are comparatively high in pollen zone 2 compared to the surface samples. Pteridophyte spores account for $1.3-13.8$ and $0.3-15.3 \%$, respectively, in pollen zone 2 and the surface samples.

Pollen zone 3 (230-190 cm: 19350-17930 cal yr BP): in this zone, tree and shrub pollen maintains a dominant status $(79.7-92.2 \%)$, followed by herbs $(5.2-13.7 \%)$, ferns $(0.7-7.1 \%)$ and aquatics $(0-5.8 \%)$. The percentage of trees and shrubs reaches its highest value $(92.2 \%)$ of the profile, at a depth of $200 \mathrm{~cm}$. The conifers $(28.4-66.8 \%)$ show a higher percentage than broad-leaved trees (19-51.4\%). Pinus (19.2-50.0\%) and Abies (9.0-43.4\%) pollen shows a sharp increase, and Abies pollen in particular maintains a peak value $(43.4 \%)$ throughout the profile. The broadleaved trees Quercus (9.5-31.1\%) and Betula (1.3-9.6\%), and herbaceous Artemisia (0-11.2\%) also play an important role. The ferns are dominated by Athyriaceae, ranging from 0.2 to $7.1 \%$. Six other types of ferns, i.e. Polypodi- aceae, Selaginellaceae, Sinopteridaceae, Hymenophyllaceae, Pteris and Lygodiaceae, occur at low percentages, less than $2 \%$. The prevalence of Myriophyllum (0-2.8\%) and Pediastrum $(0-5.8 \%)$ declines sharply, and one new aquatic taxon, Potamogetonaceae, appears in this zone at a low percentage $(0-0.1 \%)$.

The percentage of tree and shrub pollen in pollen zone $3(79.7-92.2 \%)$ is more similar than the previous zones to that of the surface samples $(79.5-97 \%)$. As in the surface samples, Pinus pollen dominates in pollen zone 3, followed by Abies and Quercus. The percentages of herb pollen (pollen zone 3: 5.2-13.7\%; surface samples: 1.8-4.1\%) and aquatics (pollen zone 3: 0-5.8\%; surface samples: 0-3\%) in pollen zone 3 are higher than in the surface samples. However, a comparatively lower percentage of pteridophyte spores is recorded in pollen zone $3(0.7-7.1 \%)$ than in the surface samples $(0.3-15.3 \%)$.

Pollen zone 4 (190-80 cm: 17930-9250 cal yr BP): tree and shrub pollen dominates in this zone (75.8-90.4\%). Herbs rank second $(7.5-18.4 \%)$, followed by ferns $(0$ $12.1 \%)$ and aquatics (0-4\%). Coniferous Pinus (12.6$46.9 \%)$ and Abies $(1.8-30.3 \%)$ as well as broad-leaved Quercus (9.1-37.8\%) and Betula (0-13.5\%) are the dominant elements of trees and shrubs. Additionally, three other coniferous taxa, Picea, Tsuga and Taxodiaceae, and 28 broad-leaved tree species, including Corylus, Castanopsis, Liquidambar and Myrsinaceae, are recorded at low percentages. Herbs are represented by Artemisia (0-9.9\%), Labiatae $(0-6.1 \%)$ and Polygonaceae $(0.4-4.7 \%)$, accompanied by Chenopodiaceae, Cyperaceae, Plantaginaceae and Gramineae in minute quantities. Nine types of ferns are found in this zone, among which Athyriaceae and Polypodiaceae possess relatively high percentages of $0-12.1$ and $0-2.2 \%$, respectively. Three aquatic plants occur: Myriophyllum (0-3.7\%), Pediastrum (0-0.6\%) and Zygnema (0$0.2 \%)$.

Tree and shrub pollen maintains a dominant status in pollen zone $4(75.8-90.4 \%)$ and in the surface samples (79.5-97\%). Pinus pollen dominates the pollen assemblage of pollen zone $4(12.6-46.9 \%)$, but its percentage is much lower than in the surface samples $(62.3-87.1 \%)$. The percentages of Quercus (pollen zone 4: 9.1-37.8\%; surface samples: 0-5.5\%) and Abies pollen (pollen zone 4: 1.8$30.3 \%$; surface samples: $3.3-10.7 \%$ ) in pollen zone 4 are generally higher than in the surface samples. A comparatively higher percentage of herb pollen is documented in pollen zone $4(7.5-18.4 \%)$ relative to the surface samples (1.8-4.1\%). Pteridophyte spores (pollen zone 4: 0-12\%; surface samples: $0.3-15.3 \%$ ) and aquatics (pollen zone 4 : 0-4\%; surface samples: 0-3\%) occur in similar percentages in pollen zone 4 and the surface samples.

Pollen zone 5 (80-0 cm: 9250 cal yr BP-present): this zone is dominated by tree and shrub pollen (47-84.2\%), followed by herbs $(4.9-37.4 \%)$, ferns $(7.8-24.8 \%)$ and aquatics $(0$ $3 \%)$. The pollen percentage of conifers $(31.3-79.9 \%)$ is 
higher than that of broad-leaved trees (4.3-37.6\%). From the beginning to the end of this zone, Pinus (14-56.8\%) shows a decrease then increases sharply, while Quercus (1-29.1\%) and Betula (0-7.4\%) show a decreasing trend, and Abies (7.4-27.2\%) an increasing one. Tsuga (1.1-7.5\%) reaches its highest percentage in this zone. Pollen of other trees and shrubs such as Picea, Alnus, Corylus, Carpinus, Ericaceae, Anacardiaceae, Dipsacaceae, Flacourtiaceae and Meliaceae are found in some samples, at percentages of less than $1 \%$. Herbs are characterized by a distinct decrease in Artemisia $(0-3.4 \%)$ and an increase in Polygonaceae (2-20.8\%) and Labiatae (0.7-15.4\%). Among the fern spores, Polypodiaceae $(4.5-17.9 \%)$ shows a remarkable increase and Athyriaceae $(0-6.3 \%)$ a notable decrease. The percentage of aquatics changes little compared to pollen zone 4, but Myriophyllum disappears in this zone. Thus only two types are recorded: Pediastrum (0-0.6\%) and Zygnema (0-3\%).

Tree and shrub pollen dominates the pollen assemblages of both pollen zone 5 and the surface samples, represented by $47-84.2 \%$ and 79.5-97\%, respectively, among which $P i$ nus, Abies and Quercus are the dominant taxa. The percentages of herb pollen (pollen zone 5: 4.9-37.4\%; surface samples: $1.8-4.1 \%$ ) and pteridophyte spores (pollen zone $5: 7.8-$ $24.8 \%$; surface samples: $0.3-15.3 \%$ ) are generally greater in pollen zone 5 than in the surface samples. Aquatics occur at the same percentage (0-3\%) in pollen zone 5 and the surface samples.

\section{Discussion and conclusions}

\subsection{Climatic implications of the principal palynomorphs from Wenhai Lake}

The palynoflora found in the Wenhai core includes a large number of potential climate indicators. For example, Pinus is currently distributed below $3200 \mathrm{~m}$ elevation in Southwest China and is commonly found in slightly warm and moderately dry habitats. Pinus yunnanensis Franch., P. densata Mast. and $P$. armandi Franch. are the dominant species on the mountains of northwestern Yunnan (KIBCAS, 1986). Tsuga is a cold-tolerant and hygrophilous conifer, requiring a MAT of 8.4 to $10.5^{\circ} \mathrm{C}$ and a MAP of about $1000 \mathrm{~mm}$ for favourable growth in Yunnan (WGYV, 1987). One species, Tsuga dumosa (D. Don) Eichler, and one variety, T. chinensis (Franch.) E. Pritz. var. forrestii (Downie) Silba, are recorded in northwestern Yunnan (KIBCAS, 1986; Wang et al., 2007). Abies is strongly associated with cold and dry habitats with a MAT of $2-8^{\circ} \mathrm{C}$ and MAP of ca. $600 \mathrm{~mm}$ in the mountains of Southwest China (CCCV, 1980; Jarvis, 1993). Five species (viz. Abies delavayi Franch, A. forrestii C. Rogers, A. georgei Orr, A. nukiangensis W. C. Cheng and L. K. Fu, and A. ferreana Bordères and Gaussen) and two varieties (A. ernestii Rehd. var. salouenensis (Borderes et Gaussen) W. C. Cheng et L. K. Fu and A. georgei Orr var. smithii (Viguie et Gaussen) W. C. Cheng et L. K. Fu) occur in northwestern Yunnan (KIBCAS, 1986). Betula is viewed as a cold- and drought-tolerant element. Eleven species and two varieties occur in Yunnan, among which five species and two varieties grow in Lijiang, including $B$. calcicola (W. W. Smith) Hu, B. delavayi Franch, B. platyphylla Suk., B. utilis D. Don, B. potaninii Batal, B. utilis D. Don var. sinensis (Franch.) H. Winkl, and B. delavayi Franch. var. polyneura Hu ex. P. C. Li (KIBCAS, 1991). Alnus usually grows on riverbanks or at village margins, in moist temperate habitats. One species, A. nepalensis D. Don, is found in northwestern Yunnan (KIBCAS, 1991). Evergreen sclerophyllous Quercus displays considerable ecological adaptability, and can grow in either dry or humid environments. This genus is widely distributed in the fog zone (with higher humidity, at about $3100 \mathrm{~m}$ ) on Jade Dragon Snow Mountain, where it forms a montane needle- and broad-leaved mixed forest along with Tsuga and Picea (WGYV, 1987). From our personal observations, some small Quercus trees are present up to about $3800 \mathrm{~m}$. Artemisia is mainly distributed in temperate areas of mid- to high latitudes of the Northern Hemisphere, usually in arid or semi-arid environments (Valles and McArthur, 2001). The genus Artemisia is considered an indicator of steppe climate (Erdtman, 1952) and moderate precipitation (El-Moslimany, 1990). There are 54 species and 8 varieties growing in Yunnan (KIBCAS, 2003a). Cyperaceae is a cosmopolitan family with ca. 5000 species and 104 genera. Many species of this family commonly grow in wetlands and surrounding areas, adapted to open and sunny conditions. About 26 genera and 272 species occur in Yunnan. The high frequency of Cyperaceae pollen may indicate humid conditions (KIBCAS, 2003b; Sun et al. 2003).

\subsection{Vegetation and climate history at Wenhai}

Based on the climatic preferences of the major taxa recovered from the Wenhai core, the palynological record reveals a detailed history of shifting vegetation and climate change in this region during the past 22570 years (Fig. 3). From 22570 to 21140 cal yr BP (pollen zone 1), the vegetation surrounding the lake catchment was dominated by broad-leaved forest (composed mainly of Quercus, Betula and Castanopsis), accompanied by needle-leaved forest (mainly Pinus and Abies). The herbaceous plants Artemisia, Labiatae, Compositae and Polygonaceae, as well as ferns Athyriaceae, Polypodiaceae, Gymnogrammaceae and Pteris, grew around the lake or under coniferous or broad-leaved trees. This pollen assemblage indicates a rather cold and dry climate relative to the present followed by cold and wet conditions. Between 21140 and 19350 cal yr BP (pollen zone 2), the vegetation was dominated by broad-leaved forest and needle-leaved forest as before, with a notable increase in Betula pollen and a sharp decrease in Quercus pollen, reflecting a relatively cold and dry climate with several fluctuations in humidity during this period. From 19350 to $17930 \mathrm{cal} \mathrm{yr} \mathrm{BP}$ (pollen zone 

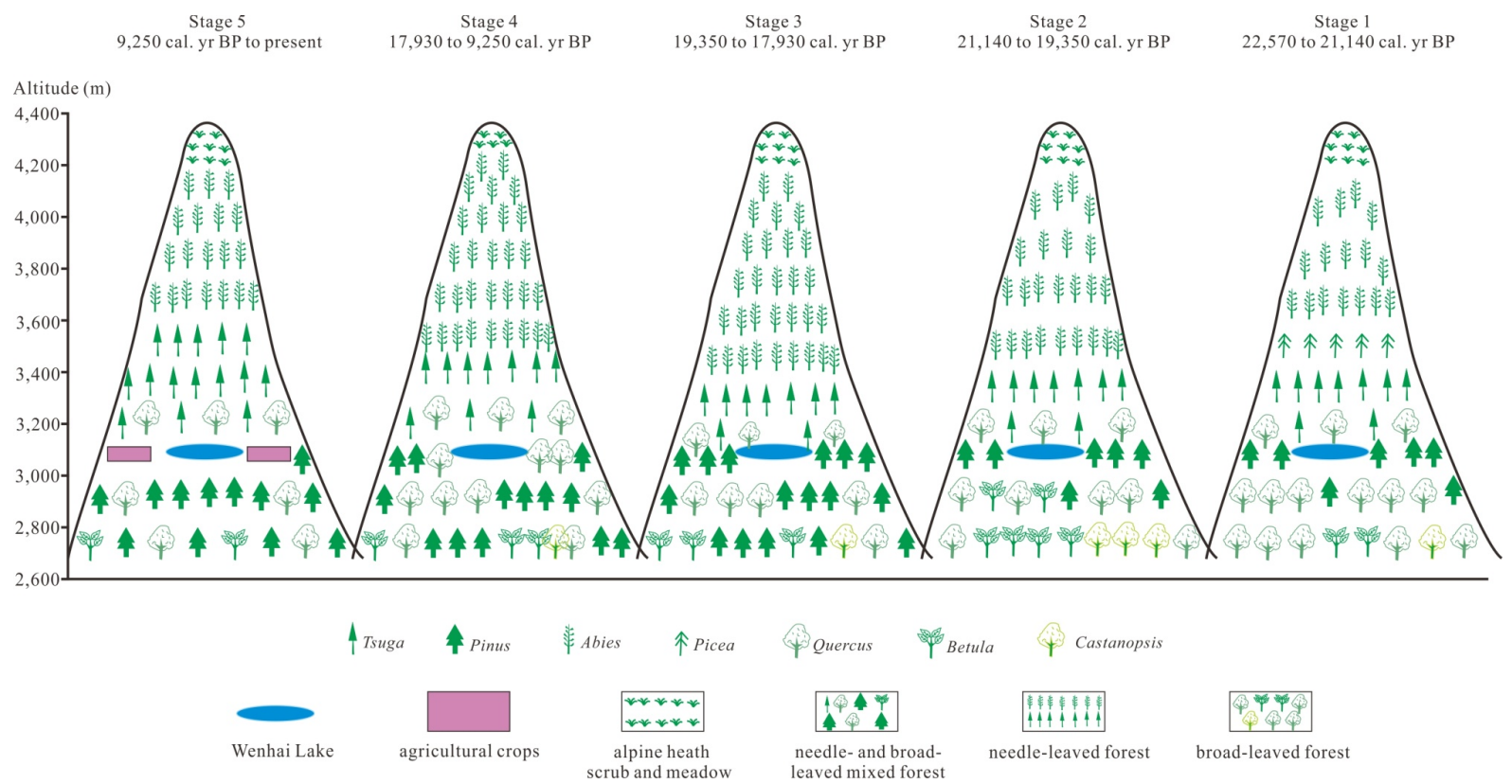

Quercus Betula Castanopsis scrub and meadow
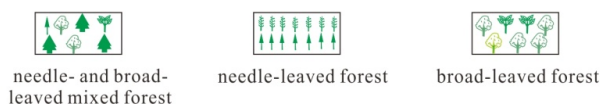

Figure 3. Schematic diagrams showing vegetation succession over the past 22570 years at Wenhai.

3), the coniferous trees Pinus and Abies showed a distinct increase, with Abies especially reaching its maximum proportion during this period. In contrast, broad-leaved Quercus displayed a remarkable decrease compared to the previous stage. This pollen assemblage suggests a transition from broad-leaved forest to needle-leaved forest, pointing to the coldest and driest climate conditions since 22570 cal yr BP. In the period from 22570 to 17930 cal yr BP, needle-leaved forest dominated by Pinus and Abies gradually expanded and reached a maximum extent, and at the same time, the extent of Betula increased. This period might correspond to the cold Last Glacial Maximum (LGM). However, the exact start and end dates of the LGM in Southwest China have been the subject of much debate. For example, Chen et al. (2014) reported that the LGM occurred between 29200 and 17600 cal yr BP, based on the expansion and maximum extent of cold-temperature coniferous forest (mainly Abies/Picea) in the Xingyun Lake catchment of central Yunnan. Long et al. (1991) identified that the LGM occurred from 30000 to 15000 years BP, with coverage of conifer and broad-leaved mixed forest in the Qilu Lake catchment of central Yunnan. Jiang et al. (2001) concluded that the LGM occurred from 33000 to 16000 years BP, with vegetation comprising montane mixed coniferous and broad-leaved forest and sclerophyllous evergreen oaks in the Heqing Basin of northwestern Yunnan. Thus, previous palynological records from Yunnan tend to provide broader estimates for the LGM. In the present paper, because the basal age of the Wenhai core reaches only to $22570 \mathrm{cal} \mathrm{yr} \mathrm{BP}$, we cannot deduce the date of the start of the LGM, which perhaps occurred prior to the inferred basal age, as evidenced by the relatively low pollen sum compared with pollen zones 4 and 5 . Between 17930 and 9250 cal yr BP (pollen zone 4), coniferous forest and broad-leaved forest began to decline and increase, respectively, until $140 \mathrm{~cm}$ depth of the core, reflecting increases in temperature and humidity relative to pollen zone 3 . From $140 \mathrm{~cm}$ to $110 \mathrm{~cm}$, coniferous forest expanded, but broadleaved forest gradually shrank, which indicates colder and drier climate conditions, likely corresponding to the Younger Dryas cold event (YD). The YD is also recorded by other studies in Yunnan. For example, Shen et al. (2006) pointed to the relatively cold period of 12950 to $11750 \mathrm{cal} \mathrm{yr} \mathrm{BP}$ as the YD, based on the dominance of Betula and deciduous oaks in the Erhai Lake catchment. Xiao et al. (2014) identified a relatively cold phase between 12230 and 11510 cal yr BP, based on the dominance of open alpine meadow around Tiancai Lake. From 9250 cal yr BP to the present day (pollen zone 5), Pinus underwent a process of decrease at the depth of 50 $80 \mathrm{~cm}$ (from 38.1 to $14 \%$ ), increase from 30 to $50 \mathrm{~cm}$ (from 14 to $56.8 \%$; this shows a trend consistent with the Haligu core between 4000 and $2400 \mathrm{cal} \mathrm{yr}$ BP), and decrease again at $0-30 \mathrm{~cm}$ (from 56.8 to $14.5 \%$ ), while Tsuga displays an opposite trend. Abies shows a distinct increase during this period. Quercus increased at the beginning of the stage, then decreased after that. This pollen assemblage indicates that needle-leaved forest (comprising mainly Pinus, Abies and Tsuga) dominated the areas surrounding Wenhai Lake during the Holocene, interspersed with broad-leaved elements (mainly Quercus and Betula), reflecting a significant decline in humidity from the early to late Holocene, which might be related to a strong Asian summer monsoon over Southwest China during the early Holocene and a reduced monsoon in- 
tensity in the mid- to late Holocene (Dykoski et al., 2005; Kramer et al., 2010).

\subsection{Palynological signals of human activity detected in the Wenhai core}

Based on pollen and other evidence, human influences on postglacial vegetation have been inferred in Europe and North America (e.g. Brugam, 1978; Hirons and Edwards, 1986; Smith and Cloutman, 1988; Russell et al., 1993; Parker et al., 2002), as well as in China (e.g. An et al., 2002; He et al., 2002; Xu et al., 2002; Song et al., 2012). The present authors have previously published another palynological investigation within the Hengduan Mountains (Song et al., 2012). The altitude of the previous study site, Haligu, is $3277 \mathrm{~m}$, where there is no current human settlement. The present study area, about $2 \mathrm{~km}$ far from Haligu, is close to a Naxi ethnic minority settlement at Wenhai village. Moreover, Wenhai was an important stop on the ancient "Tea-Horse Road" (Luo, 2003), making it likely that a wide variety of cultivated plants were introduced into the agricultural system around the lake, as evidenced by an ethnobotanical survey of traditional edible plants (including 45 cultivated plants) used by the Naxi people in Wenhai village (Zhang et al., 2013).

In the Wenhai core, several observations may be interpreted in terms of increasing anthropogenic impact in the region. First, Pinus and Quercus pollen decreased distinctly at the depth of $0-30 \mathrm{~cm}$, which is probably linked with the fact that local people felled the trees for house construction or fuel wood. We detected that Quercus pollen decreased steadily in the Haligu core during the period from 2400 cal yr BP to the present day and observed heavy present-day coppicing of Quercus for firewood, resulting in much reduced pollen production. The comparison of both cores may substantiate the existing human impacts in the region. Second, the occurrence of abundant Labiatae pollen also indicates increasing human activity. From our personal observation, the Naxi people in Wenhai village currently cultivate several Labiatae species, including Perilla frutescens (L.) Britton and Mentha spp., as edible herbs and for medical utilization. Third, the increase in Polygonaceae pollen (likely to be Fagopyrum) could be an important indicator of human activity in the region, as the Naxi people continue to plant buckwheat as an important crop today. Although we have no absolute way to confirm these signals correlated with increased human settlement in the region, we believe a further ongoing study of two soil pit profiles with high-resolution dating and sampling from the village of Wenhai will give us even more information about human activity on Jade Dragon Snow Mountain.

\section{The Supplement related to this article is available online} at doi:10.5194/bg-12-1525-2015-supplement.
Acknowledgements. The authors thank Nai-Qiu Du from the Institute of Botany, Chinese Academy of Sciences, and ShaoHua Yang from the Institute of Alpine Plants in Yunnan Academy of Agricultural Sciences for their help with this study. This study was supported by the China National Key Basic Research Program (no. 2014CB954201), the National Natural Science Foundation of China (no. 41271222), and a visiting scholarship funded by the China Scholarship Council (no. 201204910043).

Edited by: F. Wittmann

\section{References}

An, C. B., Chen, F. H., and Feng, Z. D.: Study on the relationship between the vegetation change and the human activities in the Gangsu-Qinghai region during the period from mid- to lateHolocene, Arid. Land. Geogr., 25, 160-164, 2002 (in Chinese with English abstract).

An, C. B., Tao, S. C., Zhao, J. J., Chen, F. H., Lv, Y. B., Dong, W. M., Li, H., Zhao, Y. T., Jin, M., and Wang, Z. L.: Late Quaternary (30.7-9.0 cal ka BP) vegetation history in Central Asia inferred from pollen records of Lake Balikun, northwest China, J. Paleolimnol., 49, 145-154, 2013.

Bronk, R.: OxCal Program v3.10, University of Oxford Radiocarbon Accelerator Unit, 2005.

Brugam, R. B.: Pollen indicators of land-use change in southern Connecticut, Quat. Res., 9, 349-362, 1978.

Cao, X., Ni, J., Herzschuh, U., Wang, Y., and Zhao, Y.: A late Quaternary pollen dataset from eastern continental Asia for vegetation and climate reconstructions: Set up and evaluation, Rev. Palaeobot. Palyno., 194, 21-37, 2013.

CCCV (Compilation Committee of Chinese Vegetation): Vegetation of China, Science Press, Beijing, 1980 (in Chinese).

Chen, X. M., Chen, F. H., Zhou, A. F., Huang, X. Z., Tang, L. Y., Wu, D., Zhang, X. J., and Yu, J. Q.: Vegetation history, climatic changes and Indian summer monsoon evolution during the Last Glaciation (36400-13400 cal yr BP) documented by sediments from Xinyun Lake, Yunnan, China, Palaegeogr. Palaeoclimatol. Palaeoecol., 410, 179-189, 2014.

Conservation International: The Biodiversity Hotspots, available at: http://www.biodiversityhotspots.org/ (retrieved: 22 June 2012), 2010.

Cook, C. G., Jones, R. T., and Turney, C. M.: Catchment instability and Asian summer monsoon variability during the early Holocene in southwestern China, Boreas, 42, 224-235, 2013.

Dykoski, C. A., Edwards, R. L., Cheng, H., Yuan, D. X., Cai, Y. J., Zhang, M. L., Lin, Y. S., Qing, J. M., An, Z. S., and Revenaugh, J.: A high-resolution, absolute-dated Holocene and deglacial Asian monsoon record from Dongge Cave, Earth Planet. Sci. Lett., 233, 71-86, 2005.

El-Moslimany, A. P.: Ecological significance of common nonarboreal pollen: examples from dry lands of the Middle East, Rev. Palaeobot. Palyno., 64, 343-350, 1990.

Erdtman, G.: Pollen morphology and plant taxonomy (Angiosperms. an introduction to palynology-I), Almqvist and Wiksell, Stockholm, 1952.

Erdtman, G.: The acetolysis method, revised description, Svensk Botanisk Tidskrskrift, 54, 561-564, 1960. 
Feng, J. M., Wang, X. P., Xu, C. D., Yang, Y. H., and Fang, J. Y.: Altitudinal patterns of plant species diversity and community structure on Yulong Mountains, Yunnan, China, J. Mt. Sci., 24 , 110116, 2006 (in Chinese with English abstract).

Foster, G. C., Chiverrell, R. C., Harvey, A. M., Dearing, J. A., and Dunsford, H.: Catchment hydro-geomorphological responses to environmental change in the Southern Uplands of Scotland, Holocene, 18, 935-950, 2008.

Grimm, E.: TILIA version 1.11, Illinois State Museum, Springfield, USA, 1997.

He, X. B., Tang, K. L., Tian, J. L., and Matthews, J. A.: Paleopedological investigation of three agricultural loess soils on the Loess Plateau of China, Soil Sci., 167, 478-491, 2002.

He, Y. Q., Yao, T. D., Yang, M. X., and Shen, Y. P.: Contemporary significance of snow and ice indicated by the record in a shallow ice core from a temperate glacier in southwestern monsoon region, J. Glaciology Geocryology, 22, 235-242, 2000a (in Chinese with English abstract).

He, Y. Q., Yao, T. D., Yang, M. X., and Sun, W. Z.: The new results of $\delta^{18} \mathrm{O}$ studies on the system of precipitation, snow, ice and glacial runoff at the glacier Baishui No. 1 region in Mt. Yulong, China, J. Glaciology Geocryology, 22, 391-393, 2000b (in Chinese with English abstract).

Hirons, K. R. and Edwards, K. J.: Events at and around the first and second Ulmus declines: Palaeoecological investigations in Co. Tyrone, Northern Ireland, New Phytol., 104, 131-153, 1986.

IBCAS (Institute of Botany, Chinese Academy of Sciences): Spore pteridophytorum sinicorum, Science Press, Beijing, 1976 (in Chinese).

IBSCIBCAS (Institute of Botany and South China Institute of Botany, Chinese Academy of Sciences): Angiosperm pollen flora of tropic and subtropic China, Science Press, Beijing, 1982 (in Chinese).

Jarvis, D. I.: Pollen evidence of changing Holocene monsoon climate in Sichuan Province, China, Quat. Res., 39, 325-337, 1993.

Jiang, Q. F., Ji, J. F., Shen, J., Ryo, M., Tong, G. B., Qian, P., Ren, X. M., and Yan, D. Z.: Holocene vegetational and climatic variation in westerly-dominated areas of Central Asia inferred from the Sayram Lake in northern Xinjiang, China, Sci. China Ser. D, 56, 339-353, 2013.

Jiang, X. Z., Wang, S. M., and Yang, X. D.: Paleoclimatic and environmental changes over the last 30000 years in Heqing Basin, Yunnan Province, J. Lake Sci., 10, 10-16, 1998 (in Chinese with English abstract).

Jiang, X. Z., Yang, X. D., Wang, S. M., and Tong, G. B.: The Last Glacier Maximum pollen record in the lake sediments from ancient Heqing Lake and its significance for palaeomonsoon, Acta Micropalaeontol. Sin., 18, 263-267, 2001 (in Chinese with English abstract).

Jones, R. T., Cook, C. G., Zhang, E. L., Langdon, P. G., Jordan, J., and Turney, C.: Holocene environmental change at Lake Shudu, Yunnan Province, southwestern China, Hydrobiologia, 693, 223235, 2012.

KIBCAS (Kunming Institute of Botany, Chinese Academy of Sciences): Flora Yunnanica (Tomus 4), Science Press, Beijing, 1986 (in Chinese).

KIBCAS (Kunming Institute of Botany, Chinese Academy of Sciences): Flora Yunnanica (Tomus 5), Science Press, Beijing, 1991 (in Chinese).
KIBCAS (Kunming Institute of Botany, Chinese Academy of Sciences): Flora Yunnanica (Tomus 13). Science Press, Beijing, 2003a (in Chinese).

KIBCAS (Kunming Institute of Botany, Chinese Academy of Sciences): Flora Yunnanica (Tomus 15). Science Press, Beijing, 2003b (in Chinese).

Kramer, A., Herzschuh, U., Mischke, S., and Zhang, C. J.: Holocene treeline shifts and monsoon variability in the Hengduan Mountains (southeastern Tibetan Plateau), implications from palynological investigations, Palaeogeogr. Palaeoclimatol. Palaeoecol., 286, 23-41, 2010.

Li, X. Q. and Du, N. Q.: The acid-alkali-free analysis of Quaternary pollen, Acta Bot. Sin., 41, 782-784, 1999 (in Chinese with English abstract).

Li, X. Q., Zhao, K. L., Dodson, J., and Zhou, X. Y.: Moisture dynamics in central Asia for the last $15 \mathrm{kyr}$ : new evidence from Yili Valley, Xinjiang, NW China, Quat. Sci. Rev., 30, 3457-3466, 2011.

Long, R. H., Li, B. F., Brenner, M., and Song, X. L.: A study of late Pleistocene to Holocene vegetation in Qilu Lake of central Yunnan, Geol. Yunnan, 10, 105-118, 1991 (in Chinese with English abstract).

Luo, S. W.: The historical route of the ancient "Tea-Horse Road" and the current value of its tourism development, J. Chongqing Norm. Uni. (Nat. Sci. Ed.), 20, 54-57, 2003 (in Chinese with English abstract).

Mook, W. G.: Recommendations/resolutions adopted by the Twelfth International Radiocarbon Conference, Radiocarbon, 28, p. 799, 1986.

Moore, P. D., Webb, J. A., and Collinson, M. E.: Pollen analysis, 2nd Ed., Blackwell Scientific Publications, London, 1991.

Myers, N., Mittermeier, R. A., Mittermeier, C. G., da Fonseca, G. A. B., and Kent, J.: Biodiversity hotspots for conservation priorities, Nature, 403, 853-858, 2000.

Parker, A. G., Goudie, A. S., Anderson, D. E., Robinson, M., and Bonsall, C.: A review of the mid-Holocene elm decline in the British Isles, Prog. Phys. Geog., 26, 1-45, 2002.

Reimer, P. J., Baillie, M. G. L., Bard, E., Bayliss, A., Beck, J. W., Bertrand, C. J. H., Blackwell, P. G., Buck, C. E., Burr, G. S., Cutler, K. B., Damon, P. E., Edwards, R. L., Fairbanks, R. G., Friedrich, M., Guilderson, T. P., Hogg, A. G., Hughen, K. A., Kromer, B., McCormac, G., Manning, S., Ramsey, C. B., Reimer, R. W., Remmele, S., Southon, J. R., Stuiver, M., Talamo, S., Taylor, F. W., van der Plicht, J., and Weyhenmeyer, C. E.: IntCal04 terrestrial radiocarbon age calibration, 0-26 cal kyr BP, Radiocarbon, 46, 1029-1058, 2004.

Russell, E. W. B., Davis, R. B., Anderson, R. S., Rhodes, T. E., and Anderson, D. S.: Recent centuries of vegetational change in the glaciated north-eastern United States, J. Ecol., 81, 647-664, 1993.

Shen, J., Jones, R. T., Yang, X. D., Dearing, J. A., and Wang, S. M.: The Holocene vegetation history of Lake Erhai, Yunnan Province southwestern China: the role of climate and human forcings, Holocene, 16, 265-276, 2006.

Smith, A. G. and Cloutman, E. W.: Reconstruction of Holocene vegetation history in three dimensions at Waun-Fignen-Felen, an upland site in South Wales, Philos. Trans. R. Soc. London, Ser. B. Biol. Sci., 322, 159-219, 1988. 
Song, X. Y., Yao, Y. F., Wortley, A. H., Paudiyal, K. N., Yang, S. H., Li, C. S., and Blackmore, S.: Holocene vegetation and climate history at Haligu on the Jade Dragon snow mountain, Yunan, SW China, Climatic Change, 113, 841-866, 2012.

Sun, X. J., Luo, Y. L., Huang, F., Tian, J., and Wang, P. X.: Deep-sea pollen from the South China Sea: Pleistocene indicators of east Asian monsoon, Mar. Geol., 201, 97-118, 2003.

Valles, J. and McArthur, E. D.: Artemisia systematics and phylogeny- cytogenetic and molecular in sights. in: Shrubland ecosystem genetics and biodiversity: proceedings, edited by: McArthur, E. D. and Fairbanks, D. J., 13-15 June 2000, US Department of Agriculture Forest Service, Rocky Mountain Research Station, Provo, UT Ogden, USA, 67-74, 2001.

Wang, F. X., Chien, N. F., Zhang, Y. L., and Yang, H. Q.: Pollen flora of China, Science Press, Beijing, 1995 (in Chinese).

Wang, H., Zhang, C. Q., Li, D. Z., Xue, R. G., and Yang, Q. E.: Checklist of seed plants of Lijiang Alpine Botanic Garden, Yunnan Science and Technology Press, Kunming, 2007 (in Chinese).

WGYV (Writing Group of Yunnan Vegetation): Vegetation of Yunnan, Science Press, Beijing, 1987 (in Chinese).

Wu, Z. K., Zhang, C. Q., Huang, Y., Zhang, J. L., and Sun, B. L.: Analysis on the formation of plant species diversity in the Yulong Mountains, upper reaches of Yangtze River, Resources and Environment in the Yangtze Basin, 15, 48-53, 2006 (in Chinese with English abstract)
Xiao, J. L., Xu, Q. H., Nakamura, T., Yang, X. L., Liang, W. D., and Inouchi, Y.: Holocene vegetation variation in the Daihai Lake region of north-central China: a direct indication of the Asian monsoon climatic history, Quat. Sci. Rev., 23, 1669-1679, 2004.

Xiao, X. Y., Haberle, S. G., Shen, J., Yang, X. D., Han, Y., Zhang, E. L., and Wang, S. M.: Latest Pleistocene and Holocene vegetation and climate history inferred from an alpine lacustrine record, northwestern Yunnan Province, southwestern China, Quat. Sci. Rev., 86, 35-48, 2014.

Xu, Q. H., Kong, Z. C., Yang, X. L., Liang, W. D., and Sun, L. M.: Vegetation changes and human influences on Qian'an Basin since the middle Holocene, J. Integr. Plant Biol., 44, 611-616, 2002.

Ying, J. S.: Species diversity and distribution pattern of seed plants in China, Biodivers. Sci., 9, 393-398, 2001.

Zhang, L. L., Zhang, Y., Wang, L., and Wang, Y. H.: An ethnobotanical study of traditional edible plants used by Naxi people in northwest Yunnan, China -a case study in Wenhai village, Plant Divers. Resour., 35, 479-486, 2013.

Zhao, Y., Yu, Z. C., Chen, F. H., Ito, E., and Zhao, C.: Holocene vegetation and climate history at Hurleg Lake in the Qaidam Basin, northwest China, Rev. Palaeobot. Palyno., 145, 275-288, 2007. 